Int. J. Morphol.,

32(1):125-130, 2014.

\title{
Classification and Analysis of Fifth Pair of Sacral Foramina in Indian Dry Sacra
}

\author{
Clasificación y Análisis del Quinto Par de Forámenes en Huesos Sacros Secos de Indios
}

\author{
Rajani Singh
}

SINGH, R. Classification and analyses of fifth pair of sacral foramina in Indian dry sacra. Int. J. Morphol., 32(1):125-130, 2014.

SUMMARY: A sacrum with five pairs of foramina is an anatomical variant resulting from sacralisation of lumbar vertebra at cranial end or sacralisation of coccyx vertebra at caudal end. An unusual gross variation nurtures interest of anatomists and causes concern for clinicians when it mimics pathology. A sacrum with fifth anomalous pair of sacral foramina has been observed which prompted the author to examine the available sacra in the osteology lab of Department of Anatomy KG Medical University Lucknow, UP, India. Of the total sixty six observed sacra, those with five pairs of sacral foramina due to sacralisation of lumbar vertebra were found in eleven cases $(16.6 \%)$ while those due to sacralisation of coccygeal vertebra were observed in nine cases (13.6\%). These sacralisations were classified in five categories to systematise the anatomical study, causes and clinical complications. Sacralisation of lumbar vertebra may compress the fifth sacral nerve causing sciatica and back pain. It may also cause herniation of disc above sacralisation. Sacralisation of coccygeal vertebra may influence the caudal block anaesthesia in surgical procedures and also results in prolonged second stage of labor and perineal tears.

KEY WORDS: Caudal block ; Coccyx; Sacral foramen; Sacrum; Vertebra.

\section{INTRODUCTION}

The normal formula of the human vertebral column is Cervical-7, Thoracic-12, Lumbar-5, Sacral-5, Coccygeal-4 totalling to 33 vertebrae. Variations from above mentioned configuration of vertebrae occur in $20 \%$ of skeletons. Total number of segments seldom varies. Normal sacrum is formed by fusion of five sacral vertebrae creating four pairs of sacral foramina which transmit sacral nerves. Occurrence of five pairs of sacral foramina is an anatomical variant which is generated due to inclusion of an extra vertebra either at the cranial end or at the caudal end of sacrum. At the cranial end there may be fusion of fifth lumbar vertebra with the first sacral vertebra resulting in sacralisation of lumbar vertebra. Similarly at the caudal end, there may be fusion of first coccygeal vertebra with the fifth sacral vertebra or apex of sacrum which is known as sacralisation of coccygeal vertebra. Therefore, addition of a vertebra to sacral region is always accompanied with the loss of vertebra from lumbar or coccygeal region. Numerical variability is greatest at sacro-coccygeal junction and. Similar variations are also seen at lumbosacral junction. Though this is a common anatomical variant of sacrum at cranial end i.e. lumbar region but very scanty literature is available related to caudal end i.e. coccygeal region yet it is worth studying not only in different population and geographical regions to successfully deal with ailments related to sacralisation and the comparison of data in these populations with those of the world but also to enhance the data base of anatomical variants of sacrum.

Six pairs of sacral foramina have also been reported. This may be outcome of acquisitions of fifth lumbar vertebra at cranial end and coccygeal vertebra at caudal end. These seven vertebrae create six pairs of sacral foramina.

Due to sacralisation of lumbar vertebra there could be difficulty in numbering the vertebrae and modification in the configuration of lumbosacral transitional vertebra for various surgical interventions around sacral region. There may be herniation of disc above sacralisation Otani et al. (2001), associated with back pain and fifth sacral nerve may be compressed leading to sciatica. The lambosacral transitional 
vertebra transmits the weight of upper trunk of human body therefore the problems related with biomechanical movements of waist may crop up.

Sacralisation of coccygeal vertebra may cause coccydynia, caudal block failure, difficult second stage of labour and perineal tear. Thus knowledge of sacralisation of lumbar and coccygeal vertebra leading to formation of five pairs of sacral foramina is of paramount importance to physicians, surgeons and obstetricians. In addition to this, there is paucity of literature or almost no literature on sacralisation of coccygeal vertebra; therefore, the study has been carried out.

\section{MATERIAL AND METHOD}

During routine osteology demonstration classes of MBBS students, a sacrum with five pairs of sacral foramina was observed by the author. This incidence and rational thinking prompted the author to examine all available sacra totalling to sixty six in the osteology lab of KG Medical University Lucknow, UP, India. Sacra with fifth pair of sacral foramina have been been classified into five types and causes of sacralisation have been described. The statistical analysis in terms of incidence/frequency of five pairs of sacral foramina in the dry human sixty six classified sacra and associated clinical significance were brought out.

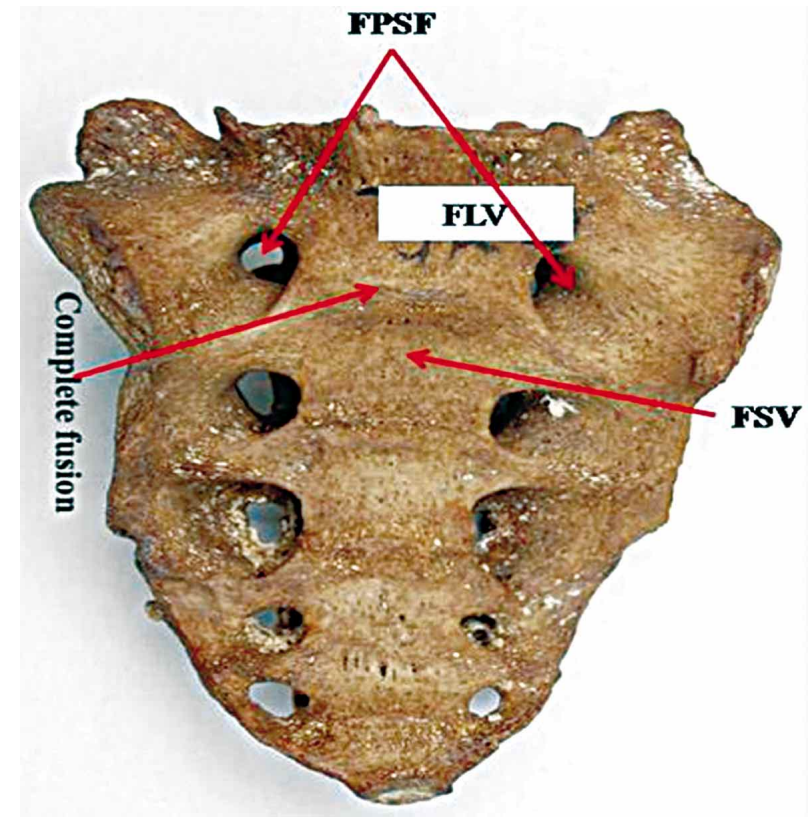

Fig. 1. Shows type-1 sacrum with complete lumbar sacralisation. FPSFFifth pair of sacral foramen due to sacralisation of lumbar vertebra, FLV- Fifth lumbar vertebra, FSV- First sacral vertebra, Complete fusioncomplete fusion of fifth lumbar vertebra and first sacral vertebra.

\section{RESULTS}

${ }^{\circ}$ Total sixty six saccra were examined as subject under study. Out of which 46 sacra $(68.75 \%)$ were found normal, having five vertebrae constituting four pairs of sacral foramina and remaining $20(31.25 \%)$ with anatomical anomalies of sacralisation. Though a few authors have studied lumbarization and sacralisation and classified the same in terms of complete and incomplete lumbar sacralisation but no literature is available to categorize coccygeal sacralisation. Therefore an attempt has been made to classify lumbar and coccygeal sacralisation together in this study. The classification has been correlated with causes, useful for diagnosis and clinical significance. This classification is based on author's own concept of variant anatomy of sacralised sacra having five pairs of foramina. Basic Structure of classification is illustrated below. These were grouped in two main classes of lumbar sacralisation and coccygeal sacralisation having two sub classes in lumbar and three in coccygeal sacralisation totalling to five categories such as-

Lumbar sacralisation. Type I (Fig. 1) - These types of sacra are formed by complete fusion of fifth lumbar vertebra with first sacral vertebra.

Type II (Fig. 2) - When there is complete fusion of fifth lumbar vertebra with the first sacral vertebra except body of the corresponding vertebrae, this has been categorizedas type II.

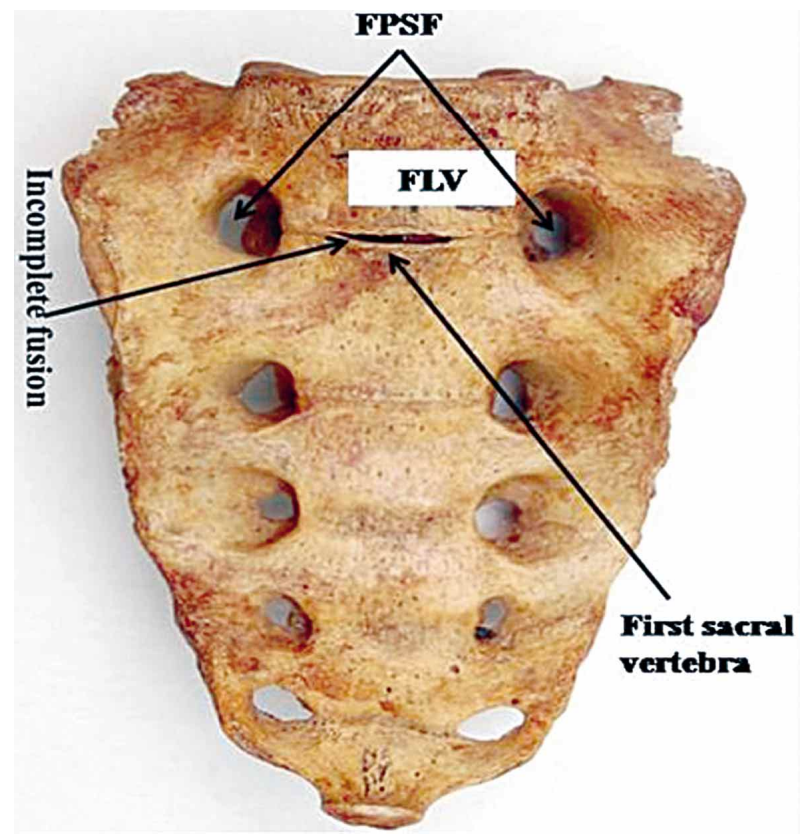

Fig. 2. Indicates type-2 sacrum with incomplete lumbar sacralisation. Incomplete fusion- expressed by gap between body of First sacral vertebra and Fifth lumbar vertebra. FPSF- Fifth pair of sacral foramen, FLV- Fifth lumbar vertebra. 


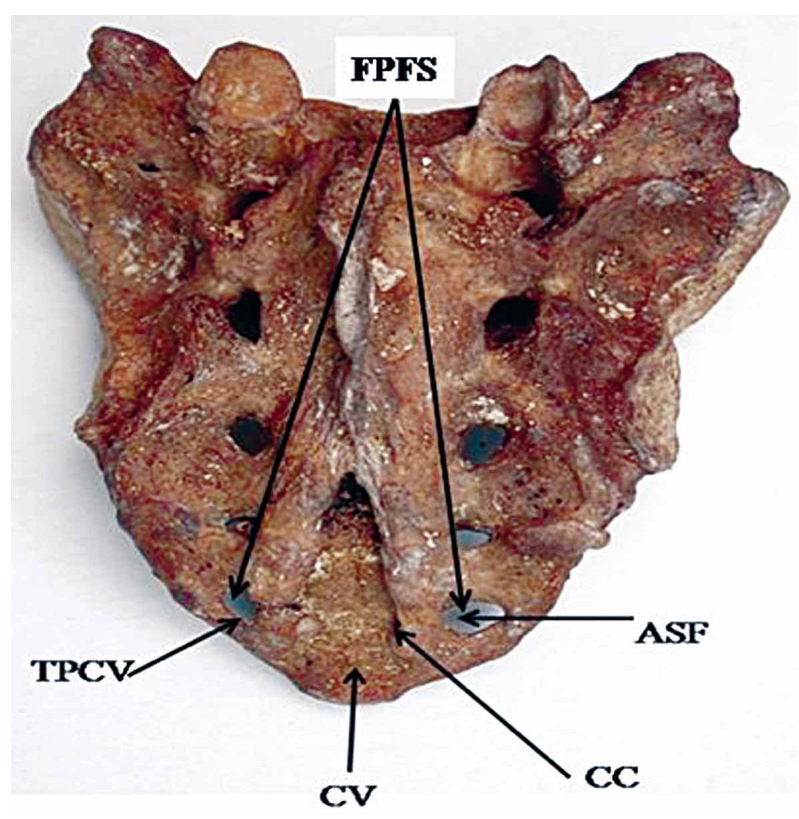

Fig. 3. Presents type-3 sacrum with complete coccygeal sacralisation (dorsal surface). TPCV- Transverse process of first coccygeal vertebra, CV- First coccygeal vertebra, CC- coccygeal cornua, ASFAdditional sacral vertebra, FPSF- Fifth pair of sacral foramen.

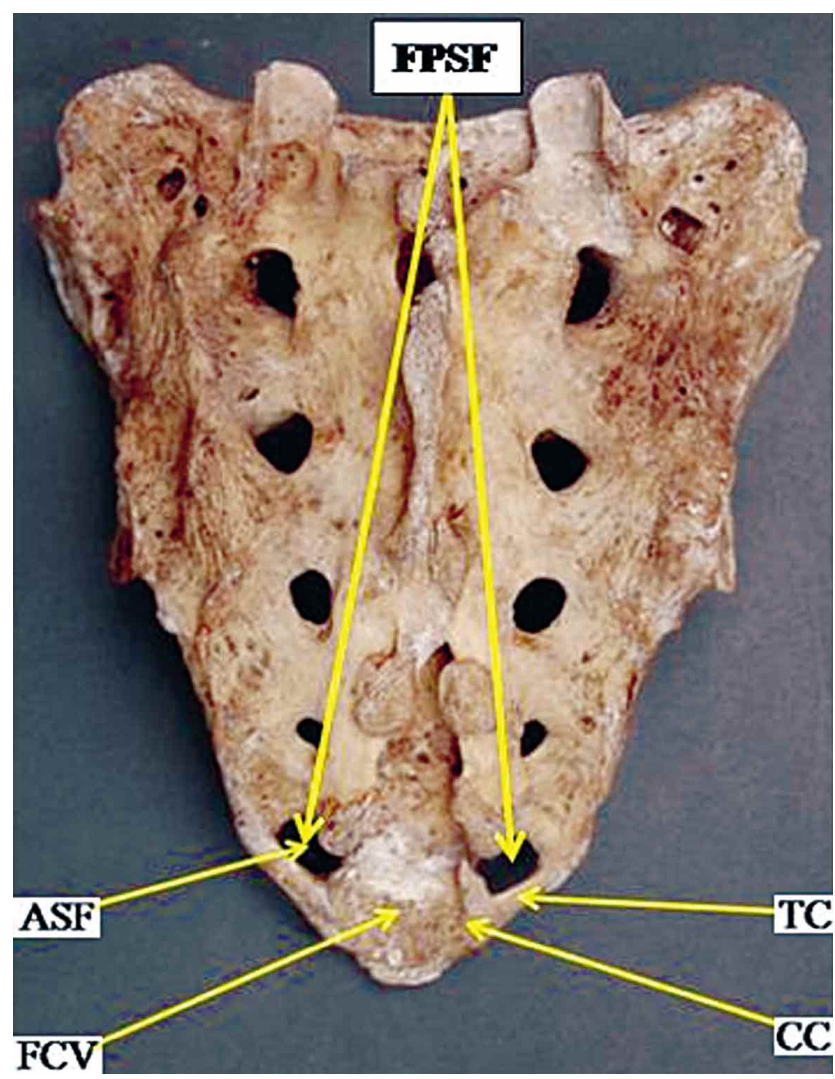

Fig. 4. Depicts type-4 sacrum with fusion of coccygeal body to the apex of sacrum and transverse process of coccygeal vertebra with the and inferior lateral angle of sacrum. ASF- Additional sacral foramen, FCV- First coccygeal vertebra, CC- Coccygeal cornua, TC- Transverse process of coccygeal vertebra, FPSF- Fifth pair of sacral foramen.
Coccygeal sacralisation. Type III (Fig. 3) - These sacra are generated by complete fusion of body, transverse process and cornua of coccygeal vertebra with corresponding elements of fifth sacral vertebra.

Type IV (Fig. 4) - Fusion of body of coccygeal vertebra with the apex of sacrum and transverse process of first coccygeal vertebra with the inferior lateral angle of sacrum. Thus completing the fifth pair laterally but it is open medially as coccygeal cornua did not fuse with sacral cornua.

Type V (Fig. 5) - Fusion of coccygeal body with apex of sacrum and cornua of coccygeal vertebra with the sacral cornua and transverse process of coccygeal vertebra does not fuse with inferior lateral angle of sacrum, completing the fifth pair medially and it is incomplete laterally.

Due to sacralisation of lumbar vertebra, eleven cases $(16.6 \%)$ were found. Out of these eleven sacra, six $(9.09 \%$ Table I) were classified as Type-I (Fig. 1) and five sacra (7.57 \% Table I) were grouped as Type-II (Fig. 2). Further, those due to sacralisation of coccygeal vertebra were detected in nine cases (13.6\%) wherein Type-III (Fig. 3) in five (7.57\%), Type-IV (Fig. 4) in two (3.03\%) and Type-V (Fig. $5)$ in remaining two sacra $(3.03 \%)$. The incidence and frequency of occurrence has been displayed in Table I.

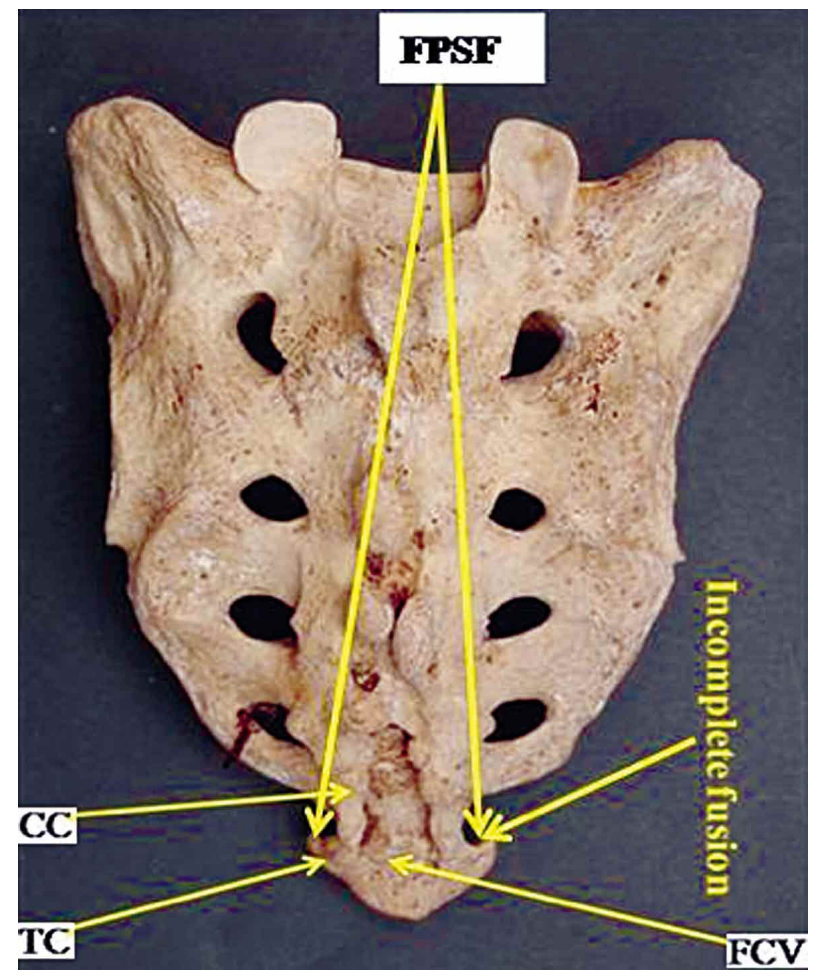

Fig. 5. Presents type-v sacrum formed by fusion of coccygeal body and apex of sacrum, coccygeal cornua to the sacral cornua CC- Coccygeal cornua, TC- Transverse process of coccygeal vertebra, FCV- First coccygeal vertebra, Incomplete fusion of transverse process. 
Table I. Incidence of sacralised classes in Indian dry sacra.

\begin{tabular}{llcc}
\hline Category & & Frequency & Incidence (\%) \\
\hline Lumbar & Type-I & 6 & 9.09 \\
Sacralisation & Type-II & 5 & 7.57 \\
& Type-III & 5 & 7.57 \\
Coccygeal & Type-IV & 2 & 3.03 \\
Sacralisation & Type-V & 2 & 3.03 \\
\hline
\end{tabular}

\section{DISCUSSION}

Five pairs of sacral foramina are formed by fusion of fifth lumber vertebra with the base of sacrum at the cranial end defined as lumber sacralisation or fusion of first coccygeal vertebra with the apex of sacrum defined as coccygeal sacralisation at the caudal end. Lumbar sacralisation is a common anatomical variant studied by a few authors. Castellvi et al. (1984) made an important contribution by studying Lumbosacral transition vertebra (LSTV) related to lower back pain in terms of lumbarization and sacralisation. He had classified lumbosacral transitional vertebra. But for systematic diagonosis and treatment of sacral ailments both the sacralisations must be classified together. The results of classification of sacralisation will enhance the database of anatomical variants of sacrum. Therefore an attempt has been made to classify dry sacralised sacra in five categories as detailed in result section of the article. This categorization has been derived from complete fusion of vertebrae to incomplete fusion of parts of the vertebrae. The sacralisation is associated with clinical implications therefore, to comprehend its degree of ossification and its completeness of fusion is essential for diagnosis of sacralisation related diseases.

The comparative study of incidence/frequency of lumber sacralisation has been brought out in Table II. There is no data available for comparision of the events of coccygeal sacralisation. Incidence of sacralisation of lumbar vertebra is
$16.6 \%$ which is close to (16\%) that studied by Bustami (1989) but lower than in Australian aboriginals (18\%) by Mitchell (1936) but higher than that in Arabs (10\%) by Bustami and in Thais (4.4\%) by Chaijaroonkhanarar et al. (2006). Incidence of sacralisation of coccygeal vertebra is $13.6 \%$ in present study. There is no literature to compare the incidence of sacralisation of coccygeal vertebra.

This varied degree of additional fusion/sacralisation as classified is produced by various causes as mutant expression of various genes or otherwise. The details appended below.

Causes of sacralisation. The vast majority of people affected by this abnormality of sacralisation are born with it i.e. it is congenital anomaly as explained embryologically belowDuring the $41 / 2$ th week of human embryo, the vertebral column develops from ventromedial portion of the somite known as sclerotome. Each segment of sclerotome migrates from both sides to surround the neural tube and the notocord at the midline of the body plane. During the 5th week, each segment of sclerotome is divided into cranial and caudal portions. The cranial area further develops to form the vertebral body whereas the caudal part develops to form the intervening disc (Moore \& Persaud, 2003).

The formation of vertebral body and neural arch are considered to be regulated by the respective homeobox and paired-box genes, Pax 1 and Pax 9 control cell proliferation during early sclerotome development Walin et al. (1993; Peter et al., 1999). As revealed in mice that were deficient for one functional copy of Pax 1, heterozygosity and homozygosity of the Pax 9 mutation result in vertebral malformations in the lumbar region, such as fused and split vertebrae, as well as ossified fusions between vertebrae and neural arches Peter $e t$ al. Thus, the intervertebral disc cartilage between fifth lumbar and first sacral vertebrae calcified to become a sacralisation of the fifth lumbar vertebra may be caused by some genetic determinants of these morphological changes from the somite

Table II. Comparision of incidences of lumbar sacralisation, Type-I and Type-II with our study.

\begin{tabular}{|c|c|c|c|c|}
\hline \multirow{2}{*}{ Studied by } & \multirow{2}{*}{$\begin{array}{c}\text { Incidences } \\
\%\end{array}$} & \multirow{2}{*}{ Ethnicity } & \multicolumn{2}{|c|}{ Classification } \\
\hline & & & Type-I \% & Type-II\% \\
\hline Mitchell (1936) & 18.0 & Original Australians & \multicolumn{2}{|c|}{ No data } \\
\hline Current study & 16.7 & North Indians & 9.1 & 7.6 \\
\hline Bustami (1989) & 16.0 & Indians & \multicolumn{2}{|c|}{ No data } \\
\hline Bustami (1989) & 10.0 & Arabians & \multicolumn{2}{|c|}{ No data } \\
\hline Brailsford (1928) & 8.1 & Englishmen & \multicolumn{2}{|c|}{ No data } \\
\hline Chaijaroonkhanarak et al. (2006) & 4.4 & Thais & 1.9 & 2.5 \\
\hline Moore \& Illinois (1925) & 3.6 & Americans & \multicolumn{2}{|c|}{ No data } \\
\hline Moore ) & 5.0 & Not mentioned & \multicolumn{2}{|c|}{ No data } \\
\hline
\end{tabular}


to vertebrae Wumnee et al. This hypothesis was supported by a previous study of Tini et al. (1977), as increased incidences of lumbosacral transitional vertebrae were observed occurring within families.

The Hoxl1 group is essential for the genesis of sacral and caudal vertebrae Wellik \& Capecchi (2003), and thus, their overexpression is expected to produce signs of sacralization or caudalization at other levels of the axial skeleton. While formation of sacral structures is apparently instructed by the expression of Hox group 11 genes in the presomitic mesoderm, caudal vertebrae seem to require the activity of these genes in the somites. Interestingly, both areas are affected when all six Hox group 11 alleles are inactivated Wellik \& Capecchi. At late developmental stages Hox group 11 genes seem to be active in somites fated to form caudal rather than sacral vertebrae (Burke et al., 1995). Thus sacralisation of coccygeal vertebra with apex of sacrum is also caused by overexpression of Hox 11 genes in the somite stage.

Studies on vertebrate model systems suggest that the evolution of HOX gene functions has allowed for the acquisition of specific morphological features along both the vertebral column and limbs of tetrapods. Gene targeting studies have also revealed region-specific functions of HOX genes alone developing digestive and genitor-urinary tracts. It has been shown that anomalous activity of the Notch, Wnt, and Fgf signalling pathways in the presomitic mesoderm also produces Hox-like transformations in the axial skeleton (Cordes et al., 2004). Regulatory genes for conversion of the mesenchyme into an epithelium of nephron appear to involve Pax 2 and wnt4. Thus, sacralisation of fifth lumbar and first coccygeal vertebra may be associated with other skeletal deformity like cervical rib or genito-urinary tract anomalies in human beings. The study can be extended to confirm this hypothesis.

Other less common reason of sacralisation include traumatic with back injury, extreme arthritic changes and purposeful spinal fusion surgery.

Clinical significance of five pairs of foramina due to sacralisation of lumbar vertebra.. Due to fusion of fifth lumber vertebra to sacrum, fifth sacral nerve may be compressed resulting in sciatica and back pain. But the back pain in sacralised sacrum is controversial as many patients with this anomaly do not complain of back pain. According to Quinhan et al. (2006), sacralisation should be kept in mind while dealing with young individuals with back pain. As in adults it may be one of the important reasons of back pain but in elderly people, other causes of back pain may also be responsible besides sacralisation of lumber vertebra.
Presence of sacralised fifth lumbar vertebra may create difficulty in identifying the lumbar level corresponding to an emerging/exiting nerve root at the time of spinal block. Thus a full radiologic examination must be performed when sacralised fifth lumbar vertebra is suspected before a lumbar epidural injection or selective nerve root block to prevent any intra -operative confusion over level identification of vertebra (Hughes \& Saifuddin, 2006).

The function of lumbosacral nerve roots is altered in patients with sacralised fifth lumber vertebra and that fourth lumbar nerve root serves the usual function of fifth lumbar nerve root. This may create confusion to physician and radiologist.

Sacralisation of fifth lumber vertebra increases the risk of early degeneration in the upper disc but the degeneration process is slowed down in lower disc. Otani $e t$ $a l$. is of view that sacralisation of fifth lumbar vertebra does not influence the incidence of nerve root symptoms. However, this condition in patients with disc herniation or lumbar canal stenosis may be a risk factor for the development of nerve root symptoms.

Obstetrical outcome of sacralised fifth lumber vertebra. In erect posture, plane of pelvic inlet makes an angle of $55^{\circ}$ with horizontal and known as angle of inclination. Angle of inclination increases due to sacralisation of lumbar vertebra which creates following problems: There is delay in engagement of head of foetus as uterine axis does not coincide with that of inlet of pelvis. It favors occipito-posterior position of foetal head which is not common position encountered in normal delivery and may lead to difficult labor. There is difficulty in descent of head of foetus due to long birth canal. It interferes with internal rotation of head of foetus.

Biomechanical effects. Weight transmission of trunk of human body takes place through LSTV. In case of lumbar sacralisation, sacrum to which weight is transmitted starts from sacralised first sacral vertebra whereas transmission is executed by last lumbar vertebra which in this case is fourth. But in normal case, the weight is transmitted by fifth lumbar vertebra to sacrum through unsacralised first sacral vertebra. This creates a change of center of gravity putting many anatomical structures under stress which may create multi-fold pathological problems such as irritation of surrounding structures may be caused during rotation, forward/ backward, dextral/lateral movement of trunk.

Perpetual shifting of center of gravity may force certain structures to get overused causing additional ossification creating other complications. The cascading effect of this may be deleterious to other organs of body. 
Clinical Significance of five pairs of foramina due to sacralisation of coccygeal vertebra. Normally four pairs of sacral foramina present in sacrum and transmit upper four sacral nerves and fifth pair of sacral nerve emerges out through the sacral hiatus. However, sacralisation of coccygeal vertebra lead to formation of five pairs of foramina and fifth pair transmits the fifth sacral nerve and coccygeal nerve. Caudal anaesthesia is most popular regional block in children. It is also employed for providing post operative analgesia after genitourinary, lower abdomen and lower limb operations. In absence of knowledge of coccygeal sacralisation, there may be nerve block failure or inadequate analgesia after surgical procedures.
Obstetrical outcome of sacralisation of coccygeal vertebra. Usually first coccygeal vertebra is mobile and during second stage of labour it is pushed posteriorly. This results in increase in antero-posterior diameter of the outlet of the pelvis, thus facilitating delivery of baby. When coccyx is fused with sacrum, it becomes fixed. The antero-posterior diameter of outlet does not increase and this may lead to prolonged labour and perineal tear. It may also cause difficult forceps delivery. Hence, screening of all pregnant women for sacralisation of coccygeal vertebra is recommended.

SINGH, R. Clasificación y análisis del quinto par de forámenes en huesos sacros secos de Indios.Int. J. Morphol., 32(1):125-130, 2014.

RESUMEN: Un sacro con cinco pares de forámenes es una variante anatómica que resulta de la sacralización de la vértebra lumbar al extremo craneal o sacralización de la vértebra coxis al extremo caudal. Esta variación inusual es de interés para los anatomistas como también motivo de preocupación para los médicos al asemejar una patología. Un sacro con un quinto par anómalo de forámenes fue observado, por lo que se examinaron otros sacros del laboratorio de osteología del Departamento de Anatomía Médica de la Universidad de Lucknow, India. De un total de 66 sacros estudiados, en 11 casos $(16,6 \%)$ se observaron cinco pares de forámenes sacros, debido a la sacralización de la vértebra lumbar; mientras que en 9 casos (13,6\%), se observó la sacralización de la vértebra caudal. Estos fueron clasificados en cinco categorías para sistematizar el estudio anatómico, sus causas y complicaciones clínicas. La sacralización de la vértebra lumbar puede comprimir el quinto nervio, causando ciática sacra y dolor de espalda. También puede causar una hernia discal superior a la sacralización. La sacralización de la vértebra caudal, puede influir en la anestesia de bloqueo caudal en procedimientos quirúrgicos y también dar lugar a una prolongada etapa del trabajo de parto y desgarros perineales.

PALABRAS CLAVE: Bloqueo caudal; Coxis; Foramen sacro; Sacro; Vértebra.

\section{REFERENCES}

Burke, A. C.; Nelson, C. E.; Morgan, B. A. \& Tabin, C. Hox genes and the evolution of vertebrate axial morphology. Development, 121(2):333-46, 1995.

Bustami, F. The anatomical features and functional significance of lumbar transitional vertebra. Jordan Med. J., 23(1):49-59, 1989.

Castellvi, A. E.; Goldstein, L. A. \& Chan, D. P. Lumbosacral transitional vertebra and their relationship with lumbar extradural defects. Spine, 9(5):493-5, 1984.

Chaijaroonkhanarar, W.; Umka, J.; Buranarugsa, M. \& Namking, M. Sacralisation of 5 th lumbar vertebra in Thais. Srinagarind Med. J., 21(3):194-9, 2006.

Cordes, R.; Schuster-Gossler, K.; Serth, K. \& Gossler, A. Specification of vertebral identity is coupled to Notch signalling and the segmentation clock. Development, 131(6):1221-33, 2004.

Hughes, R. J. \& Saifuddin, A. Numbering of Lumbosacral Transitional Vertebra on MRI: Role of the iliolumbar ligaments. AJR Am. J. Roentgenol., 187(1):W59-65, 2006.

Mitchell, G. A. G. The significance of lumbosacral transitional vertebrae. Brit. J. Surg., 24(93):147-58, 1936.

Moore, K. L. \& Persaud, T. V. N. The skeletal system; Before we are born: Essentials of embryology and birth defects. $6^{\text {th }}$ ed. Philadelphia, Saunders, 2003. pp.306-21.
Otani, K.; Konno, S. \& Kikuchi, S. Lumbosacral transitional vertebrae and nerve-root symptoms. J. Bone Joint Surg. Br., 83(8):1137-40, 2001.

Peter, H.; Wilm, B.; Sakai, N.; Imai, K.; Maas, R. \& Balling, R. Pax1 and Pax9 Synergistically regulate vertebral column development. Development, 126(23):5399-408, 1999.

Quinlan, J. F.; Duke, D. \& Eustace, S. Bertolotti's Syndrome. A cause of back pain in young people. J. Bone Joint Surg. Br., 88(9):1183-6, 2006.

Tini, P. G.; Wises, G. \& Zinn, W. M. The Transitional vertebra of lumbosacral spine: Its radiological classification, incidence, prevalence and clinical significance. Rheumatol. Rehabil., 16(3):180$5,1977$.

Wallin, J.; Mizutani, Y.; Imai, K.; Miyashita, N.; Moriwaki, K.; Taniguchi, M.; Koseki, H. \& Balling, R. A new Pax gene, Pax-9, maps to mouse chromosome 12. Mamm. Genome, 4(7):354-8, 1993.

Wellik, D. M. \& Capecchi, M. R. Hox10 and Hox11 genes are required to globally pattern the mammalian skeleton. Science, 301(5631):3637, 2003.

\section{Correspondence to:}

Dr. Rajani Singh

Additional Professor and HOD

Department of Anatomy

AlIMS Rshikesh UK, INDIA

Received: 03-02-2013

Accepted: 19-11-2013

E-mail: nani_sahayal@rediffmail.com 